OPEN ACCESS

Edited by:

Youji Wang,

Shanghai Ocean University, China

Reviewed by: Emna Diebbi, Carthage University, Tunisia Rina Chakrabarti,

University of Delhi, India

*Correspondence: Elena Gorokhova elena.gorokhova@aces.su.se

Specialty section: This article was submitted to Aquatic Physiology, a section of the journal Frontiers in Physiology

Received: 30 October 2021 Accepted: 08 December 2021 Published: 04 January 2022

Citation:

Gorokhova E and El-Shehawy R (2022) Antioxidant Responses in Copepods Are Driven

Primarily by Food Intake, Not by Toxin-Producing Cyanobacteria in the

Front. Physiol. 12:805646 doi: 10.3389/fphys.2021.805646

\section{Antioxidant Responses in Copepods Are Driven Primarily by Food Intake, Not by Toxin-Producing Cyanobacteria in the Diet}

\author{
Elena Gorokhova* and Rehab El-Shehawy \\ Department of Environmental Science, Stockholm University, Stockholm, Sweden
}

The association between oxidative processes and physiological responses has received much attention in ecotoxicity assessment. In the Baltic Sea, bloom-forming cyanobacterium Nodularia spumigena is a significant producer of various bioactive compounds, and both positive and adverse effects on grazers feeding in cyanobacteria blooms are reported. To elucidate the effect mechanisms and species sensitivity to the cyanobacteria-dominating diet, we exposed two Baltic copepods, Acartia bifilosa and Eurytemora affinis, to a diet consisting of toxin-producing cyanobacteria $N$. spumigena and a high-quality food Rhodomonas salina at $0-300 \mu \mathrm{g} \mathrm{C} \mathrm{L}^{-1}$; the control food was $R$. salina provided as a monodiet at the same food levels. The subcellular responses to food type and availability were assayed using a suite of biomarkers - antioxidant enzymes [superoxide dismutases (SOD), catalase (CAT), and glutathione S-transferases (GST)] and acetylcholinesterase (AChE). In parallel, we measured feeding activity using gut content (GC) assayed by realtime PCR analysis that quantified amounts of the prey DNA in copepod stomachs. As growth and reproduction endpoints, individual RNA content (a proxy for protein synthesis capacity), egg production rate (EPR), and egg viability (EV\%) were used. In both toxic and nontoxic foods, copepod GC, RNA content, and EPR increased with food availability. Antioxidant enzyme activities increased with food availability regardless of the diet type. Moreover, CAT (both copepods), SOD, and GST (A. bifilosa) were upregulated in the copepods receiving cyanobacteria; the response was detectable when adjusted for the feeding and/or growth responses. By contrast, the diet effects were not significant when food concentration was used as a co-variable. A bimodal response in AChE was observed in A. bifilosa feeding on cyanobacteria, with up to $52 \%$ increase at the lower levels (5-25 $\mu \mathrm{g} \mathrm{C} \mathrm{L}^{-1}$ ) and 32\% inhibition at the highest food concentrations. These findings contribute to the refinement of biomarker use for assessing environmental stress and mechanistic understanding of cyanobacteria effects in grazers. They also suggest that antioxidant and AChE responses to feeding activity and diet should be accounted for when using biomarker profiles in field-collected animals in the Baltic Sea and, perhaps other systems, where toxic cyanobacteria are common.

Keywords: AChE, antioxidant enzymes, Baltic zooplankton, CAT, feeding and growth indices, molecular diet analysis, GST, SOD 


\section{INTRODUCTION}

The health conditions in biota are influenced by numerous environmental factors, with oxidative stress, i.e., the imbalance between pro-oxidant and antioxidant homeostatic cellular conditions, mediating many disorders. Pro-oxidant conditions occur due to either increased generation of reactive oxygen species (ROS) or their poor quenching/scavenging into the body, potentially inducing damage to macromolecules, including proteins lipids, and DNA (Sies et al., 2017). While naturally occurring at low levels, ROS can also be induced by environmental conditions, both natural (e.g., hypoxia, UV radiation, and bioactive compounds) and anthropogenic (e.g., chemical contaminants). Antioxidant defense systems consisting of low molecular-weight antioxidants and antioxidant enzymes have evolved to reduce the pro-oxidation effects. The essential antioxidant enzymes (Pisoschi and Pop, 2015) are (i) ROS eliminating enzymes [e.g., superoxide dismutases (SOD), catalase (CAT), and peroxidases], (ii) enzymes that eliminate internal lipid peroxidation products [e.g., glutathione peroxidases], and (iii) those eliminating toxic secondary radical oxidation products [e.g., glutathione S-transferases (GST)]. A balance between ROS production and antioxidants to quench and/or scavenge them can be tipped by any additional burden of free radicals either from the environment or produced within the body, leading to oxidative stress manifested as fitness penalties.

In ecology and ecotoxicology, the antioxidant enzymes are used as biomarkers to identify natural and anthropogenic stressors and understand the physiological consequences of exposure (Monserrat et al., 2007). However, the interpretation of the measured values is seldom straightforward, with numerous difficulties related to the non-specificity of the antioxidant responses and considerable variability due to various biological and environmental factors (Cohen et al., 2009). Furthermore, feeding can also modulate these responses as high metabolic activity is associated with elevated ROS production (Sohal and Weindruch, 1996; Furuhagen et al., 2014), and suboptimal food quality may contribute to pro-oxidative processes (Zenteno et al., 2008). Therefore, assessing antioxidant biomarkers in concert with metabolic variables, such as feeding, respiration, and growth, would facilitate biomarker interpretation.

Naturally occurring bioactive compounds, such as cyanobacterial secondary metabolites, can induce oxidative stress and activate antioxidant defenses in eukaryotes (Ding and Ong, 2003; Wiegand and Pflugmacher, 2005; Amado and Monserrat, 2010). Moreover, filamentous cyanobacteria are commonly considered inadequate food because of (i) cyanotoxins, (ii) poor manageability, and (iii) low nutritional value due to low content of polyunsaturated fatty acids and sterols (Gulati and DeMott, 1997). Therefore, in zooplankton feeding on cyanobacteria, the antioxidant responses may be related to oxidative stress caused by various bioactive compounds, decreased metabolic activity due to the low food intake/assimilation, and poor nutrition value (Bednarska et al., 2014). Moreover, the variations in the overall food availability, food intake, and growth would also contribute to the redox status in these grazers (Furuhagen et al., 2014).
The enzymes SOD, CAT, and GST are commonly used for oxidative status assessment in fish (Jos et al., 2005; Persson et al., 2009) and invertebrates, e.g., mussels (Davies et al., 2005; Kankaanpää et al., 2007), crabs (Pinho et al., 2003), and copepods (Kozlowsky-Suzuki et al., 2009), exposed to cyanobacterial hepatotoxins (microcystin and nodularin). Moreover, in fish and invertebrates, cyanobacterial neurotoxins have been implicated in inhibiting acetylcholinesterase (AChE; Monserrat et al., 2007), the hydrolyzing enzyme of the neurotransmitter acetylcholine in cholinergic synapses. As various organophosphates and carbamates inhibit AChE, it is a wellestablished biomarker of pesticide exposure (Lionetto et al., 2013). Therefore, any non-specific alterations in its activity related to food intake or growth are of particular concern. Thus, the very same set of enzymes is used to assess the effects of pollution in systems, where co-exposure to cyanobacterial blooms is common, such as the Baltic Sea (Kopecka et al., 2006; Lehtonen et al., 2006; Napierska et al., 2009).

Cyanobacterial blooms are a regular feature of the Baltic Sea. Nodularia spumigena, Aphanizomenon spp., and Dolichospermum spp. are the main contributors to these blooms. Nodularia spumigena is usually the primary concern because of the cyclic pentapeptide nodularin, a protein phosphatase inhibitor similar to microcystins (Sivonen and Börner, 2008), and a broad spectrum of other metabolically active compounds (Lage et al., 2021). Virtually all pelagic and benthic species are exposed to these toxic outbreaks, which often coincides with low growth and fecundity (Koski et al., 1999; Engström-Öst et al., 2015). Most laboratory studies of mesozooplankton grazing on natural plankton assemblages show avoidance of cyanobacteria and preferential feeding on non-toxic strains (Lampert, 1987; Sellner et al., 1996). However, the evidence is accumulating that cyanobacteria contribute substantially to the diets of some copepods and mysids in situ (KozlowskySuzuki et al., 2003; Peters et al., 2006; Gorokhova, 2009; Motwani et al., 2017; Gorokhova et al., 2021). Coevolutionary histories, regular exposure, and high ingestion of toxic cyanobacteria support the idea that these animals might cope with ingested toxins. Moreover, toxin biodegradation of the copepod gut microbiome has been recently proposed as a mechanism behind successful feeding and growth during cyanobacterial blooms (Gorokhova et al., 2021). However, this does not mean that chronic exposure to the high abundances of the toxin-producing cyanobacteria induces no adverse sublethal effects.

Here, we tested the effects of exposure to the filamentous cyanobacterium N. spumigena in the copepods Acartia bifilosa and Eurytemora affinis, the dominant zooplankton species co-occurring with the cyanobacterium (Johansson et al., 2004). These copepods cope relatively well with the cyanobacteria-rich diets (Koski et al., 1999; Vehmaa et al., 2013); moreover, nodularin has been reported to induce antioxidative defenses and combat the oxidative damage, thus contributing toward maintenance of the oxidative balance in these copepods (Vehmaa et al., 2013). In line with this, low toxin retention (Guisande et al., 2002; Karjalainen et al., 2003; Kozlowsky-Suzuki et al., 2009) suggests that fairly efficient detoxification mechanisms may exist in these and, probably, other animals co-existing with toxic 
blooms, making them relevant as test species for ecotoxicological surveys. However, we expected to find stronger diet effects in A. bifilosa than E. affinis because of the higher sensitivity of the former to the cyanobacteria diet manifested as adverse effects on growth and reproduction reported in the field and laboratory studies (Motwani et al., 2017; Gorokhova et al., 2021).

\section{MATERIALS AND METHODS}

Feeding experiments with the copepods fed with cyanobacteriumrich diet and adequate non-toxic food control were conducted to assess the effects of N. spumigena on suborganismal responses [antioxidant enzymes (SOD, CAT, and GST) and neurotoxicity biomarker $\mathrm{AChE}$, food intake, and growth. The N. spumigena concentrations in the experiment corresponded to its ambient abundances in the northern Baltic proper (Hajdu et al., 2007). The food density gradient was created, and copepod feeding and growth at different food concentrations were assayed using a set of proxies to evaluate how the enzyme activities change with increasing food intake and growth status. Copepod stomach content was analyzed by real-time quantitative PCR (qPCR) with prey-specific primers (Engström-Öst et al., 2011) to assess the amount of specific food ingested. As growth proxies, individual RNA content (Höök et al., 2008; Holmborn et al., 2009) and egg production rate (EPR) were used for somatic and reproductive growth. In addition to EPR, egg viability (VE) was determined (Gorokhova, 2010) to indicate diet inadequacy and possible reproductive toxicity.

\section{Sampling and Sorting of Copepods}

Copepods for the experiments were collected in the Himmerfärden Bay, in the north-western Baltic proper $\left(58^{\circ} 59^{\prime} \mathrm{N}\right.$ $17^{\circ} 44^{\prime} \mathrm{E}$ ) in the first week of June 2008 , before the appearance of Nodularia spumigena in the water column. Zooplankton samples were taken from the upper $10 \mathrm{~m}$ by vertical hauls using a WP-2 net (mesh size $200 \mu \mathrm{m}, \varnothing 57 \mathrm{~cm}$ ) equipped with a cod-end. Surface water temperature during sampling was $14^{\circ} \mathrm{C}$, and salinity was $6.2 \%$. The tow contents were placed in large $(\sim 20 \mathrm{~L})$ insulated containers, diluted with surface water, and brought to the lab within a few hours. The containers were gently aerated until sorting commenced. With a light-trap, we separated zooplankton from phytoplankton and filtered onto $500 \mu \mathrm{m}$ sieve to retain mostly older copepodites (CIII-CVI) of A. bifilosa and E. affinis. The contribution of the developmental stages at the time of sampling was similar between the species, with CIII contributing $<10 \%$ in both copepods and CVI being the most common stage $(\sim 50 \%$ in A. bifilosa and $60 \%$ in E. affinis); the sex ratio (male/female; based on CV and CIV animals) was 0.25 in A. bifilosa and 0.36 in E. affinis. The copepods were then washed into a Petri dish and sorted under a dissecting microscope (Leica, 40x), using a wide-mouth pipette.

\section{Cyanobacterial and Algal Cultures}

Cultures were maintained in extended exponential growth through a semi-continuous harvesting regime $(\sim 30 \%$ exchange every third day) at $15^{\circ} \mathrm{C}$ and $6.5 \%$ salinity in artificial seawater (ASW; Instant Ocean ${ }^{\mathrm{TM}}$, Aquarium Systems) with constant illumination $\left(\sim 90 \mu \mathrm{mol}\right.$ photon PAR $\left.\mathrm{m}^{-2} \mathrm{~s}^{-1}\right)$. The cyanobacterium Nodularia spumigena, strain AV1, was grown in a modified Z8 nutrient solution (Sivonen et al., 1989). The largest and least edible colonies were removed by filtering on a $63-\mu \mathrm{m}$ sieve. The abundance of $N$. spumigena in the feeding media was adjusted using cell counts for stock samples $(5 \mathrm{ml})$ preserved with acid Lugol's solution and counted as $100-\mu \mathrm{m}$ filaments ( 200 units per sample) in Utermöhl chamber (Fluovert microscope, 125×); the counts were converted to carbon mass $\left(\mathrm{C}, \mu \mathrm{g} \mathrm{L}^{-1}\right)$ according to Olenina et al. (2006) and carbon content of $0.11 \mathrm{pg} \mathrm{C} \mu \mathrm{m}^{-3}$. The alga used as a high-quality food was Rhodomonas salina, strain CCAP 978/24, grown on $f / 20$ medium. The algal concentrations (cells $\mathrm{ml}^{-1}$ ) and cell size were determined using a laser particle counter, Spectrex PC-2000 (Spectrex Corp., California), and converted to carbon mass (46pg C cell ${ }^{-1}$ ) according to (Mullin et al., 1966).

\section{Experimental Setup}

A mixed community containing $\sim 130$ older copepodites of both species (CIII-CVI, prosome length $510 \pm 20$ and $525 \pm 22 \mu \mathrm{m}$ in Acartia and Eurytemora, respectively; mean \pm SD; $N=20$ ) per replicate was used. Both species contributed approximately equally in each experimental unit; Eurytemora females with egg sacks were not included. The incubations were carried out in $5 \mathrm{~L}$ plastic containers with dilutions of $N$. spumigena and $R$. salina cultures to nominal concentrations of $5,25,125$,

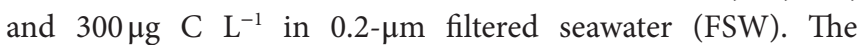
copepods were fed with either a control monodiet of $R$. salina or a mixed diet of $N$. spumigena and $R$. salina (60:40 by carbon mass); this mixture approximates cyanobacteria contribution to the Baltic phytoplankton community in the trophogenic layer during a very heavy summer bloom (Hogfors et al., 2014). Five replicates were set for each treatment, i.e., a combination of food type (i.e., N. spumigena present/absent) and food concentration. Copepods incubated in FSW served as starved control; these individuals were also used as negatives in the qPCR analysis. All experimental containers were provided with gentle aeration in a temperature-controlled room $\left(15^{\circ} \mathrm{C}\right)$ for $\sim 40 \mathrm{~h}$ and $16^{\mathrm{L}}: 8^{\mathrm{D}}$ light cycle; $\mathrm{pH}$ was monitored daily $(8.2 \pm 0.2)$.

To control for food depletion, a $20-\mathrm{ml}$ sample of the media was taken from each container every $6-8 \mathrm{~h}$; these samples were pooled within a treatment assuming a similar change in the prey concentrations. The algal and cyanobacterial cell concentrations were determined as described above and compared to the nominal concentrations in the respective treatments; if prey depletion was $>5 \%$, the food levels were reconstituted by adding the respective foods to the experimental units at the amounts required to reach the nominal concentration. During both experiments, the food concentrations decreased by no more than $17 \%$ between the checkpoints.

\section{Sampling}

Upon the experiment termination, the contents of the 5-L containers were sequentially filtered through submerged $200-\mu \mathrm{m}$ 
(to collect copepods) and 35- $\mu \mathrm{m}$ (to collect Acartia eggs) sieves. The copepods were rinsed twice with FSW, inspected for mortalities, and immobilized with $0.6 \mathrm{~g} \mathrm{~L}^{-1}$ of MS222. When present, egg sacks were separated from Eurytemora females, pooled, transferred to a depression slide (one slide per replicate), and egg number was counted using Fluovert microscope, 125×. Under a dissecting microscope, 35-40 copepods of each species from each replicate were transferred to a 1.5-ml Eppendorf tube for enzyme activity measurements and snap frozen at $-86^{\circ} \mathrm{C}$. Of the remaining copepods, two bulk samples were taken: 5 immature females (CIV) were preserved with $100 \mu \mathrm{l}$ of RNAlater for RNA measurements (Gorokhova, 2005), and 5 adult females (CV-CVI) were snap-frozen for GC qPCR analysis. All samples were kept on ice while sorting.

\section{Egg Production and Viability}

Egg production estimates (EPR, eggs females ${ }^{-1}$ ) were based on the number of eggs retained on the sieve (Acartia) or counted in the egg sacks (Eurytemora), and the number of the adult females (CVI) recovered. To assay egg viability, eggs were stained using TO-PRO-1 iodide (Gorokhova, 2010). In replicates with $<30$ eggs, all eggs were used for staining, whereas in replicates with $>30$ eggs, a random batch of $30 \pm 4$ (mean \pm SD) eggs was counted using an epifluorescence microscope with a blue filter (Leica DM IRB, $\times 100$ ). The viability was calculated as the percentage of viable eggs (VE\%).

\section{Enzyme Assays}

Each sample was homogenized $(20 \% \mathrm{wt} / \mathrm{vol})$ in a cold $\left(4^{\circ} \mathrm{C}\right)$ phosphate-buffered saline (PBS), pH 7.4, containing 1\% Triton $\mathrm{X}-100$, for $2 \mathrm{~min}$ using FastPrep homogenizer. An aliquot of the homogenate was used for the determination of the protein content, and the remaining part was centrifuged at $15000 \mathrm{~g}$ $\left(15 \mathrm{~min}, 4^{\circ} \mathrm{C}\right)$. The supernatant was used for enzyme activity assays; all assays were performed in duplicates.

The AChE activity was measured with the colorimetric assay (Ellman et al., 1961) adapted for a microplate format (Bocquené and Galgani, 1998) using a microplate reader FLUOstar Optima (BMG Labtechnologies) with absorbance configuration. Acetylthiocholine iodide (AcSCh) was used as a substrate and dithiobisnitrobenzoate (DTNB) as a reagent. To inhibit non-specific cholinesterase activity, ethopropazine- $\mathrm{HCl}\left(10^{-4} \mathrm{M}\right.$, Sigma) was added to the incubation mixture. The rate of change of absorbance at $412 \mathrm{~nm}$ due to the enzyme activity was recorded over $1.5 \mathrm{~min}\left(20^{\circ} \mathrm{C}\right)$ and expressed as nmol of AcSCh hydrolyzed $\min ^{-1} \mathrm{mg}^{-1}$ protein.

The SOD activity was measured using the spectrophotometric assay (Flohé and Ötting, 1985) adapted for a microplate format (Marie et al., 2006). The reduction rate of $2 \mu \mathrm{M}$ cytochrome $c$ was measured at $550 \mathrm{~nm}\left(20^{\circ} \mathrm{C}\right)$, in $180 \mu$ l of phosphate buffer ( $50 \mathrm{mM}, \mathrm{pH}=7.8$ ) with $0.5 \mathrm{mmol}$ EDTA, $5 \mu \mathrm{M}$ hypoxanthine and $10 \mu \mathrm{l}$ of the supernatant using FLUOstar Optima with absorbance configuration. The reaction was initiated by injecting $10 \mu \mathrm{l}$ xanthine oxidase $\left(0.2 \mathrm{U} \mathrm{ml}^{-1}\right)$. SOD activity in samples was estimated with $\mathrm{Cu}, \mathrm{Zn}$-SOD purified from bovine erythrocytes (Sigma) and expressed as $\mathrm{U}$ mg protein $^{-1}(1 \mathrm{U}$ corresponds to the SOD amount inhibiting by $50 \%$ the rate of cytochrome $c$ reduction).

The CAT activity was measured using the microplate chemiluminescence assay (Maral et al., 1977; Janssens et al., 2000) and FLUOstar Optima with luminescence configuration. The consumption of $\mathrm{H}_{2} \mathrm{O}_{2}$ by CAT was followed when $20 \mu \mathrm{l}$ of $1 \mu \mathrm{M} \mathrm{H} \mathrm{H}_{2} \mathrm{O}_{2}$ were added to $20 \mu \mathrm{l}$ of sample diluted in $80 \mu \mathrm{l}$ of phosphate buffer ( $100 \mathrm{mM}$; pH 7.8) containing 0.6 mM EDTA. After a $30-\mathrm{min}$ incubation at $25^{\circ} \mathrm{C}, 20 \mu \mathrm{l}$ of $20 \mathrm{mM}$ luminol and $11.6 \mathrm{U} \mathrm{ml}^{-1}$ horseradish peroxidase were injected, producing a light emission. The intensity of this emission was assumed to be proportional to the remaining quantity of $\mathrm{H}_{2} \mathrm{O}_{2}$. The CAT activity in the test samples was quantified by constructing standard curves using purified bovine liver CAT (Sigma-Aldrich) dissolved in the PBS-Triton buffer and expressed as $\mathrm{U} \mathrm{mg}$ protein $^{-1}$ ( $1 \mathrm{U}$ corresponds to $1 \mu \mathrm{M} \mathrm{H}_{2} \mathrm{O}_{2}$ consumed $\min ^{-1}$ ).

The GST activity was measured using the microplate spectrophotometric assay (Habig and Jakoby, 1981; Frasco and Guilhermino, 2002). The method is based on $1 \mathrm{mM}$ glutathione (GSH) conjugation with $1 \mathrm{mM}$ of 1-chloro-2.4 dinitrobenzene (CDNB) measured as absorbance decrement at $340 \mathrm{~nm}$. The measurements were taken every $20 \mathrm{~s}$ during the first $5 \mathrm{~min}$ using $100 \mu \mathrm{l}$ of the homogenate and $200 \mu \mathrm{l}$ of the reaction solution [10 mM GSH in phosphate buffer (0.1 M, pH 6.5)] and $60 \mathrm{mM}$ CDNB in ethanol using FLUOstar Optima with absorbance configuration. Enzyme activity values were expressed as $\mathrm{U}$ mg protein ${ }^{-1}$, where $1 \mathrm{U}$ is the enzyme quantity necessary to conjugate $1 \mathrm{pmol} \mathrm{CDNB} \mathrm{min}^{-1}$.

\section{Protein Concentration in the Homogenate}

All enzymatic activities were normalized to the protein concentration in the respective sample. Protein concentrations were determined by a microplate fluorometric assay using the NanoOrange Protein Quantification Kit (Molecular Probes, Inc. Eugene, OR) with bovine serum albumin standards (Jones et al., 2003). In brief, $10 \mu \mathrm{l}$ of the homogenate were diluted in NanoOrange working solution to achieve a final volume of $130 \mu \mathrm{l}$. Samples were incubated at $95^{\circ} \mathrm{C}$ for $10 \mathrm{~min}$ and cooled to room temperature for $25 \mathrm{~min}$ (light protected). Fluorescence was measured with FLUOstar Optima (filters: $485 \mathrm{~nm}$ for excitation and $590 \mathrm{~nm}$ for emission) reader and black solid flat-bottom microplates (Greiner Bio-One $\mathrm{GmbH}$ ) with an integration time of $1 \mathrm{~s}$.

\section{Quantitation of Individual RNA Content}

We used individual RNA content in CVI copepods as a measure of condition and short term growth potential; this proxy has been successfully applied for both A. bifilosa and E. affinis growth assessment in the field (Höök et al., 2008) and experimental (Gorokhova and Engström-Öst, 2009) studies. The body RNA content in the copepod samples was quantified using microplate fluorometric high-range RiboGreen (Molecular Probes, Inc. Eugene, OR) assay after extraction with $\mathrm{N}$-laurylsarcosine followed by RNase digestion (Gorokhova and Kyle, 2002). Fluorescence was measured in duplicates for each sample, standard, and negative control using FLUOstar 
Optima (filters: $485 \mathrm{~nm}$ for excitation and $520 \mathrm{~nm}$ for emission) reader and black solid flat-bottom microplates (Greiner Bio-One $\mathrm{GmbH}$ ).

\section{qPCR-Based Gut Content Analysis}

To quantify Nodularia and Rhodomonas in copepod guts (i.e., gut content, GC), a qPCR assay was applied. A 201 bp fragment of Nodularia 16S rDNA was amplified using NTS primer, TGTGATGCAAATCTCA(C/A)A (Moffitt et al., 2001) and universal 16S rRNA reverse primer 1494Rc, TACGGCTACCTTGTTACGAC (Neilan et al., 1997) following the established protocols (Gorokhova and Engström-Öst, 2009; Engström-Öst et al., 2011). A 213-bp fragment of Rhodomonas $18 \mathrm{~S}$ rDNA was amplified using Rhod 1450F primer, GCGCGCTACACTGATGAATGC, and Rhod 1662R primer, TTTCACCGGACCATTCAATCG (Troedsson et al., 2009). For DNA extraction, $50 \mu \mathrm{l}$ of $10 \%$ Chelex were added to a copepod sample and incubated for $3 \mathrm{~h}$ at $65^{\circ} \mathrm{C}$. After spinning in a centrifuge $(2 \mathrm{~min}$ at $12000 \mathrm{~g})$, the supernatant $(30 \mu \mathrm{l})$ was transferred to a clean tube and stored at $4^{\circ} \mathrm{C}$ for no more than $24 \mathrm{~h}$. To prepare the standards, defined volumes of exponentially growing Nodularia and Rhodomonas cultures were filtered onto GF/F filters and dried at $50^{\circ} \mathrm{C}$ for $24 \mathrm{~h}(\sim 1-2 \mathrm{mg}$ DW per filter). Using a punch set, a $4 \mathrm{~mm}$ circle was sub-sampled from each filter, weighed, and DNA was extracted using the Chelex method. The DNA yield per sample was quantified using PicoGreen ${ }^{\mathrm{TM}}$ dsDNA quantitation kit (Molecular Probes, Eugene, OR) and contribution of DNA to DW was determined for each prey, $0.75 \pm 0.05 \%$ for $N$. spumigena and $1.03 \pm 0.08 \%$ for $R$. salina (mean $\pm \mathrm{SD} ; n=5$ ). These percentages were assumed to remain constant during the experiment. From each experimental unit, five individuals were analyzed in bulk and the amount of prey DW individual ${ }^{-1}$ was calculated using the respective percentages of DNA and error propagation rules.

Five-point standard curves were generated using 10-fold dilutions of the extracted DNA; duplicate negative controls (water) were included in all runs. Duplicate qPCR reactions were performed using StepOne real-time cycler (Applied Biosystems) and the QuantiTect SYBR Green PCR Kit (QIAGEN). For qPCR analysis of the copepod samples, the second-lowest concentration of standard DNA was added to all samples to ensure sample concentrations occurred within the standard curve. The measured concentration of samples was later adjusted to account for this added DNA. Amplifications were performed in a $25-\mu \mathrm{l}$ reaction mixture with an initial denaturing step of $15 \mathrm{~min}$ at $95^{\circ} \mathrm{C}$, and 40 cycles of $30 \mathrm{~s}$ at $94^{\circ} \mathrm{C}, 30 \mathrm{~s}$ at $53^{\circ} \mathrm{C}$ for Nodularia and $57^{\circ} \mathrm{C}$ for Rhodomonas, and $30 \mathrm{~s}$ at $72^{\circ} \mathrm{C}$. An endpoint melt-curve analysis was generated after each run and analyzed to ensure non-specific PCR products' absence; amplification efficiencies were $92-101 \%$, with $R^{2}>0.98$. To verify the authenticity of the PCR products, a random selection was purified using the Nucleo-Spin ${ }^{\circledR}$ Extract Kit (Macherey-Nagel), sequenced using ABI 3730 PRISM $^{\circledR}$ DNA Analyzer at KIGene (Karolinska Institute, Stockholm, Sweden), and aligned with AY075067 and EU926158 (GenBank) for N. spumigena and R. salina, respectively.

\section{Statistics}

In all statistical analyses, biochemical, molecular, and physiological variables measured in each experimental unit, post-exposure were analyzed using Statistica v. 8.0 for Windows (StatSoft Inc. 2001). For each variable and each copepod species, treatment effect (diet; two levels: mixed Nodularia/Rhodomonas vs. Rhodomonas), food availability (food concentration; five levels), and their interaction were evaluated using a two-way ANOVA followed by Bonferroni's multiple comparison tests. When F-ratio statistics detected a significant interaction effect, a $t$-test was used for pair-wise comparison of treatment means. For linear statistics, $\log (\mathrm{x}+1)$ transformation was applied to RNA, EPR, VE, GC values, and enzyme activities to improve normality and homogeneity, while egg viability values (VE\%) were arcsine square-root transformed.

Further, we used generalized linear models (GLZ) on untransformed values with gamma distribution and log link function to test for the diet effects on the relationships between the enzyme activities in each copepod species and physiological variables (copepod RNA content, EPR, VE\%, and GC; continuous predictors). To establish the significant drivers of the enzymatic responses, the best-fit model was obtained using the Model Building Module in Statistica via screening the optimal number and combinations of the covariates. The best-fit model selection was based on considerations for parsimony, AIC, and residuals distribution. The variance inflation factor (VIF) set to $<3$ was used to select non-collinear variables (Zuur et al., 2010).

\section{RESULTS}

\section{Effects of Prey Species and Food Concentration on Antioxidative Enzymes}

Regardless of the diet, SOD and CAT activities significantly increased with increasing food concentrations in both species (Figures 1A-D; Table 1). Also, GST activity significantly increased with food availability (Figures 1E,F; Table 1); however, in A. bifilosa fed Nodularia, this increase occurred only below150

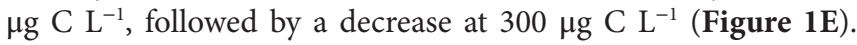
The decrease at the highest food concentration was significant compared to both non-toxic control $\left(t\right.$-test: $\left.t_{8}=4.954, p<0.001\right)$ and the next highest concentration $\left(t_{8}=7.032, p<0.0001\right)$. Moreover, significant positive correlations between all three antioxidant enzymes were observed in both copepods (Spearman rank correlation, $0.42-0.45$ and $0.56-0.64$ in A. bifilosa and E. affinis, respectively; $p<0.05$ in all cases). The diet effect was significant only for GST in both copepods and marginally significant for SOD in E. affinis, with higher activities observed in the Rhodomonas monodiet (Table 1).

\section{Effects of the Diet and Food Concentration on AChE}

A bell-shaped response in AChE activity to the food concentration in the mixed diet was observed in both copepods (Figures 1G,H). At low food availability $\left(5-25 \mu \mathrm{g} \mathrm{C} \mathrm{L}^{-1}\right)$, the mixed diet stimulated AChE activity, with values increasing up to 53 and $15 \%$ in Acartia bifilosa and Eurytemora affinis, respectively. The increase 


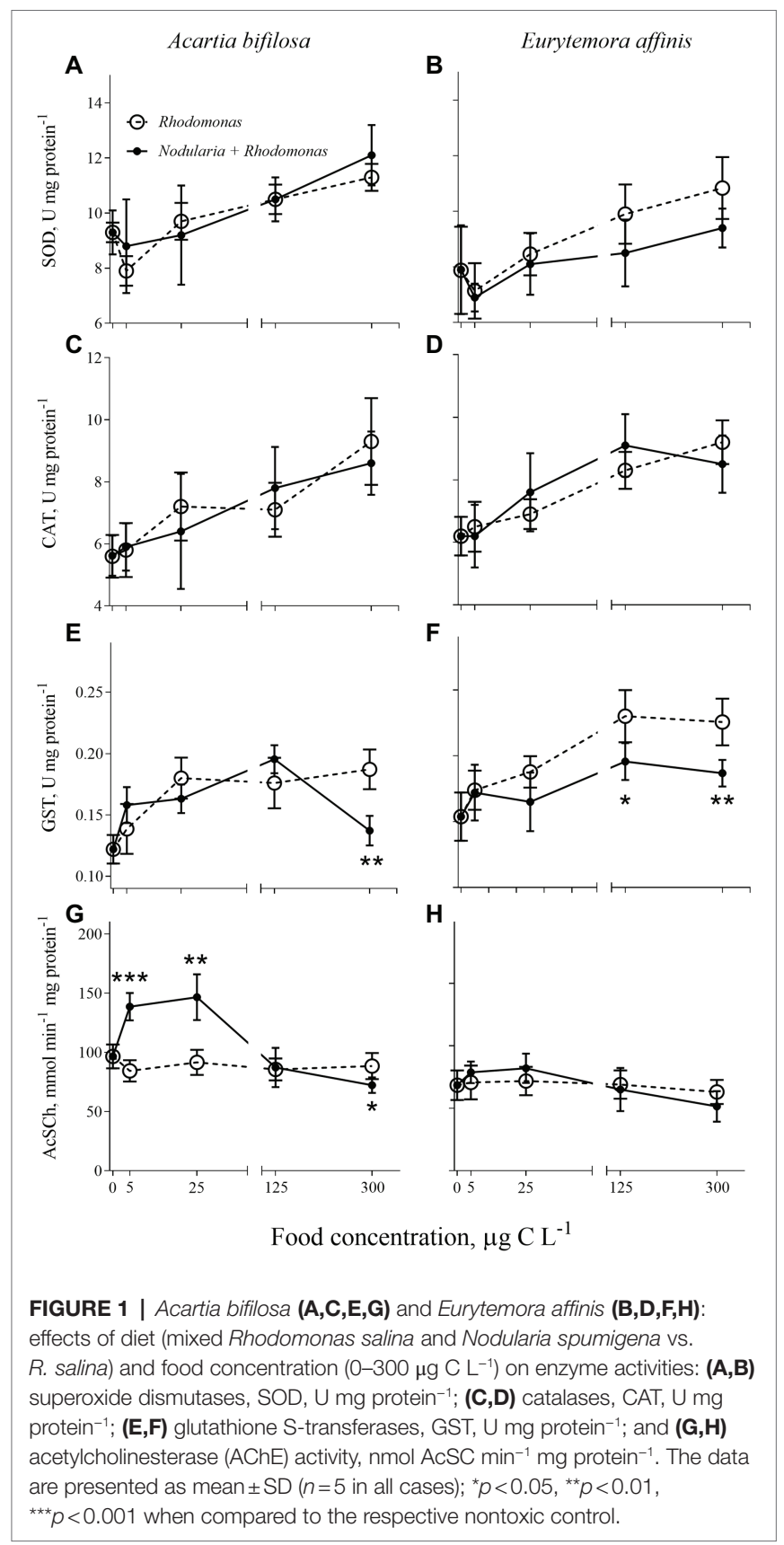

was significant in A. bifilosa when compared to the starved control $\left(t_{8}=6.617, p<0.001\right)$ and Rhodomonas monodiet $\left(t_{8}=5.997, p<0.0003\right)$, but not in any treatment with $E$. affinis ( $p>0.24$ in all cases). At the highest mixed-diet concentration, AChE activity decreased relative to the respective non-toxic control (Figures 1G,H); the decrease was significant in A. bifilosa $\left(t_{8}=2.518, p<0.04\right)$ but not in E. affinis $(p>0.17$ in all cases).

\section{Effects of the Diet and Food Concentration on Feeding, Growth, and Reproduction}

As expected, individual RNA content, EPR, and GC values responded positively to increased food concentration (significant
TABLE 1 | Two-way ANOVA; sigma-restricted parameterization, effective hypothesis decomposition: diet (Nodularia/Rhodomonas vs. Rhodomonas) and

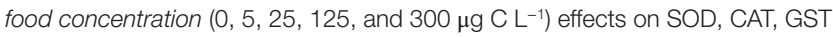
(Umg protein $\left.{ }^{-1}\right)$, and AChE (nmol AcSCh min $^{-1} \mathrm{mg}_{\text {protein }}{ }^{-1}$ ) activities in copepods.

\begin{tabular}{|c|c|c|c|c|c|}
\hline \multirow{2}{*}{ Effect } & \multirow{2}{*}{$d f$} & \multicolumn{2}{|c|}{ Acartia } & \multicolumn{2}{|c|}{ Eurytemora } \\
\hline & & $\boldsymbol{F}$ & $p$ & $F$ & $p$ \\
\hline \multicolumn{6}{|l|}{ SOD } \\
\hline $\begin{array}{l}\text { Food } \\
\text { concentration }\end{array}$ & 4 & 8.49 & $<0.001$ & 9.04 & $<0.001$ \\
\hline Diet & 1 & 0.46 & 0.501 & 3.70 & 0.061 \\
\hline $\begin{array}{l}\text { Diet } \times \text { Food } \\
\text { concentration }\end{array}$ & 4 & 0.56 & 0.689 & 0.95 & 0.444 \\
\hline \multicolumn{6}{|l|}{ CAT } \\
\hline $\begin{array}{l}\text { Food } \\
\text { concentration }\end{array}$ & 4 & 11.71 & 0.001 & 17.91 & $<0.001$ \\
\hline Diet & 1 & 0.16 & 0.659 & 0.12 & 0.732 \\
\hline $\begin{array}{l}\text { Diet } \times \text { Food } \\
\text { concentration }\end{array}$ & 4 & 0.59 & 0.644 & 1.508 & 0.218 \\
\hline \multicolumn{6}{|l|}{ GST } \\
\hline $\begin{array}{l}\text { Food } \\
\text { concentration }\end{array}$ & 4 & 20.68 & $<0.001$ & 16.16 & $<0.001$ \\
\hline Diet & 1 & 1.37 & 0.243 & 12.81 & 0.001 \\
\hline $\begin{array}{l}\text { Diet } \times \text { Food } \\
\text { concentration }\end{array}$ & 4 & 6.095 & 0.001 & 2.17 & 0.089 \\
\hline \multicolumn{6}{|l|}{ AChE } \\
\hline $\begin{array}{l}\text { Food } \\
\text { concentration }\end{array}$ & 4 & 14.65 & $<0.001$ & 3.22 & 0.022 \\
\hline Diet & 1 & 24.10 & $<0.001$ & 0.30 & 0.582 \\
\hline $\begin{array}{l}\text { Diet } \times \text { Food } \\
\text { concentration }\end{array}$ & 4 & 15.38 & $<0.001$ & 1.61 & 0.190 \\
\hline
\end{tabular}

Significant effects $(p<0.05)$ are in boldface.

in all cases; Table 2; Figure 2). Moreover, the adverse effects of Nodularia on all these variables were significant in both species ( $p<0.006$ in all cases; Table 2). In A. bifilosa, the difference in the EPR between the copepods fed mixed and mono-Rhodomonas diets increased with increasing food concentrations (Figures 2C,D); this was reflected in the significant $\operatorname{diet} \times$ food concentration interaction term (Table 2). Moreover, significant interactions for GC indicated that differences between the diets were not consistent for different food concentrations in both copepods (Table 2), increasing at higher food concentrations (Figures 2G,H).

\section{Effects of Physiological Variables on Enzyme Activities}

In Acartia bifilosa, significant positive effects of Nodularia on the antioxidant enzyme (SOD, CAT, and GST) and AChE activities were observed when accounted for the confounding effects of growth status (SOD and CAT) and/or feeding (CAT and GST; Table 3). In Eurytemora affinis, this was true for CAT activity only (Table 3). GC was a significant predictor of SOD, CAT, and GST values in the best-fit models for both species, indicating a positive effect of food intake on enzyme activities.

\section{Egg Viability}

Egg viability was significantly lower in A. bifilosa compared to E. affinis, decreasing with increased food concentration 
TABLE 2 | Two-way ANOVA; sigma-restricted parameterization, effective hypothesis decomposition: diet (Nodularia/Rhodomonas vs. Rhodomonas) and food concentration $\left(0,5,25,125\right.$, and $\left.300 \mu \mathrm{g} \mathrm{C} \mathrm{L}^{-1}\right)$ effects on individual RNA content (RNA, ng ind ${ }^{-1}$ ), egg production (EP, egg female ${ }^{-1}$ ), viability (\%EV), recruitment (viable egg female ${ }^{-1}$ ), and gut content (GC, ng DW ind ${ }^{-1}$ ) in copepods.

\begin{tabular}{|c|c|c|c|c|c|}
\hline \multirow{2}{*}{ Variables } & \multirow{2}{*}{$d f$} & \multicolumn{2}{|c|}{ Acartia } & \multicolumn{2}{|c|}{ Eurytemora } \\
\hline & & $\boldsymbol{F}$ & $p$ & $F$ & $p$ \\
\hline \multicolumn{6}{|l|}{ RNA } \\
\hline $\begin{array}{l}\text { Food } \\
\text { concentration }\end{array}$ & 4 & 9.24 & 0.001 & 6.33 & $<0.001$ \\
\hline $\begin{array}{l}\text { Diet } \\
\text { Diet } \times \text { Food } \\
\text { concentration }\end{array}$ & $\begin{array}{l}1 \\
4\end{array}$ & $\begin{array}{c}11.59 \\
1.34\end{array}$ & $\begin{array}{l}\mathbf{0 . 0 0 2} \\
0.270\end{array}$ & $\begin{array}{l}10.16 \\
1.178\end{array}$ & $\begin{array}{l}\mathbf{0 . 0 0 2} \\
0.135\end{array}$ \\
\hline \multicolumn{6}{|l|}{ EP } \\
\hline $\begin{array}{l}\text { Food } \\
\text { concentration }\end{array}$ & 4 & 6.41 & 0.001 & 11.31 & $<0.001$ \\
\hline Diet & 1 & 18.69 & $<0.001$ & 8.46 & 0.006 \\
\hline $\begin{array}{l}\text { Diet } \times \text { Food } \\
\text { concentration }\end{array}$ & 4 & 4.78 & 0.003 & 0.899 & 0.473 \\
\hline \multicolumn{6}{|l|}{ Egg viability } \\
\hline $\begin{array}{l}\text { Food } \\
\text { concentration }\end{array}$ & 4 & 1.04 & 0.398 & 1.143 & 0.3503 \\
\hline Diet & 1 & 1.01 & 0.321 & 4.614 & 0.0378 \\
\hline $\begin{array}{l}\text { Diet } \times \text { Food } \\
\text { concentration }\end{array}$ & 4 & 0.69 & 0.658 & 0.6318 & 0.6434 \\
\hline \multicolumn{6}{|l|}{ Recruitment } \\
\hline $\begin{array}{l}\text { Food } \\
\text { concentration }\end{array}$ & 4 & 5.05 & 0.0022 & 12.91 & $<0.001$ \\
\hline Diet & 1 & 10.01 & 0.0029 & 5.28 & 0.0268 \\
\hline $\begin{array}{l}\text { Diet } \times \text { Food } \\
\text { concentration }\end{array}$ & 4 & 2.26 & 0.0797 & 0.35 & 0.8416 \\
\hline \multicolumn{6}{|l|}{ GC } \\
\hline $\begin{array}{l}\text { Food } \\
\text { concentration }\end{array}$ & 4 & 49.33 & $<0.001$ & 67.63 & $<0.001$ \\
\hline Diet & 1 & 93.03 & $<0.001$ & 12.85 & 0.001 \\
\hline $\begin{array}{l}\text { Diet } \times \text { Food } \\
\text { concentration }\end{array}$ & 4 & 8.64 & 0.001 & 7.217 & 0.001 \\
\hline
\end{tabular}

Significant effects $(p<0.05)$ are in boldface.

(GLZ; diet: $t_{48}=2.95, p<0.004 ;$ copepod species: $t_{48}=3.38$, $p<0.001$ ), whereas diet $\times$ copepod species interaction was never significant (Table 2) indicating that these trends were consistent between the copepod species. Together, lower egg production and viability translated into significantly lower recruitment estimated as a product of EPR and EV\% in copepods fed mixed diet than those fed with Rhodomonas monodiet (Table 2).

Of all enzyme activities measured, the only significant predictors for the proportion of viable eggs were CAT (Acartia: Wald statistics $=5.39, p<0.02$ ) and GST (Eurytemora: Wald statistics $=4.42, p<0.03$ ), with negative and positive effects, respectively. The recruitment was significantly predicted by a combination of RNA as a positive predictor (Wald statistics $=45.21, p<0.0001$ ) and SOD as a marginally significant negative predictor (Wald statistics $=2.84, p>0.08$ ), with no significant effects of either species or diets.

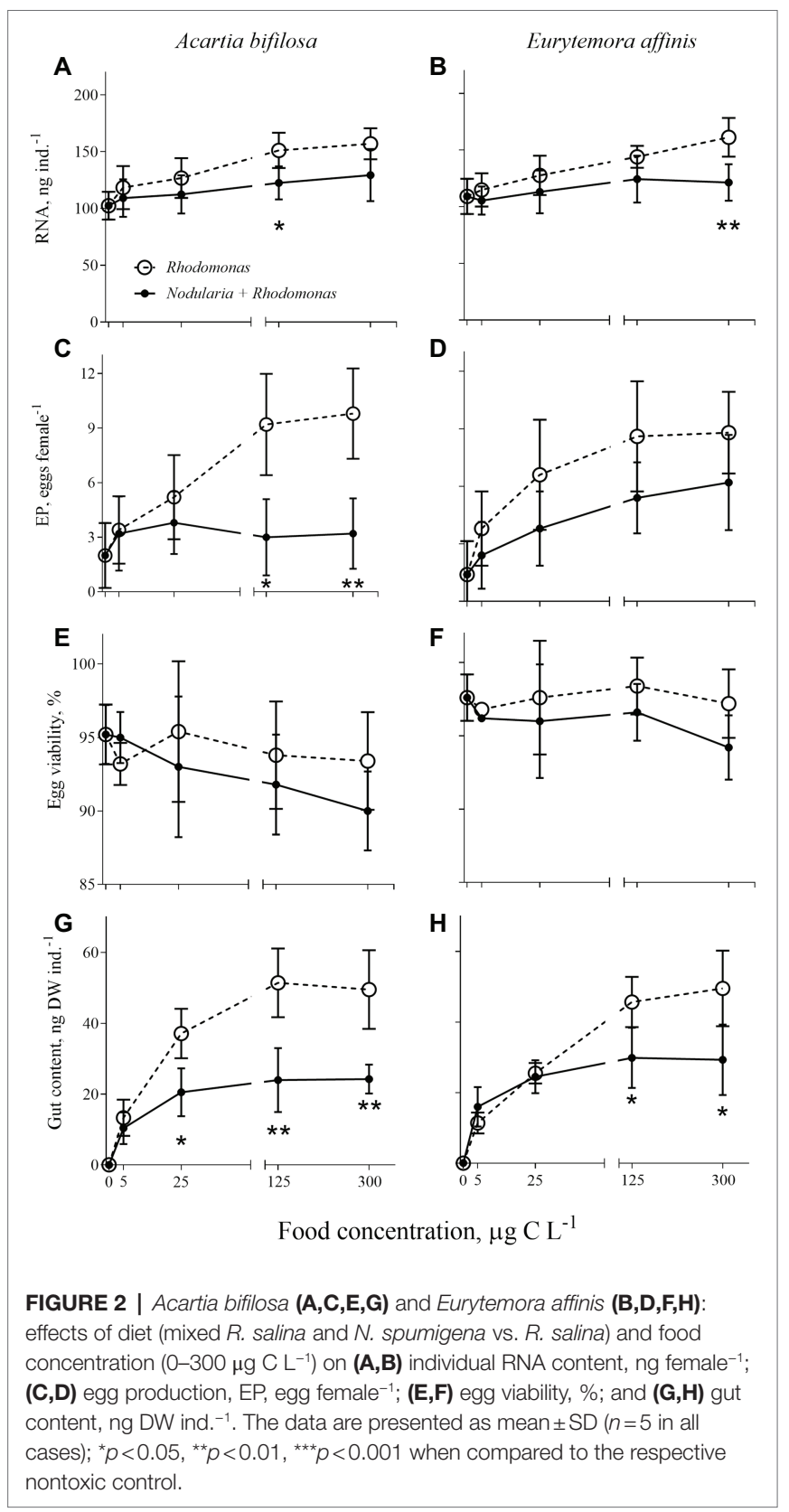

\section{DISCUSSION}

Cladocerans and copepods are test organisms in ecotoxicological testing, including biomarker applications. The challenge is to understand the biomarker variability in these highly adaptable grazers under variable environmental conditions, including food concentrations and foods with high levels of natural toxins and biologically active metabolites. Most ecotoxicological surveys employing biomarkers to identify the biological effects of contaminants ignore the natural toxins in the environment as well as food availability and growth status of the test animals. We addressed this issue by assessing biomarker (antioxidant and AChE activities), feeding, and growth responses in the 
TABLE 3 | Best-fit GLZ models for relationships between enzyme activities (AChE, SOD; CAT and GST) as response variables and diet (Nodularia/Rhodomonas vs. Rhodomonas) as the categorical independent factor and individual RNA content (RNA), egg production (EP), egg viability (EV\%), and gut content (GC) as possible continuous predictors in Acartia bifilosa and Eurytemora affinis.

\begin{tabular}{|c|c|c|c|c|c|c|}
\hline \multirow{2}{*}{ Variables } & \multicolumn{3}{|c|}{ Acartia } & \multicolumn{3}{|c|}{ Eurytemora } \\
\hline & Estimate & Wald statistics & $p$ & Estimate & Wald statistics & $p$ \\
\hline \multicolumn{7}{|l|}{ SOD } \\
\hline Diet & 0.0017 & 4.03 & 0.044 & & & \\
\hline RNA & 0.0029 & 7.90 & 0.005 & 0.0035 & 7.37 & 0.006 \\
\hline GC & 0.066 & 2.48 & 0.112 & 0.0036 & 7.23 & 0.007 \\
\hline RNA & & & & 0.0038 & 11.05 & 0.001 \\
\hline EV\% & -1.544 & 5.88 & 0.016 & & & \\
\hline $\mathrm{GC}$ & 0.0061 & 23.30 & $<0.001$ & 0.0031 & 5.54 & 0.019 \\
\hline \multicolumn{7}{|l|}{ GST } \\
\hline Diet & 0.057 & 7.34 & 0.007 & & & \\
\hline GC & 0.0052 & 13.45 & 0.004 & 0.0537 & 23.96 & $<0.001$ \\
\hline \multicolumn{7}{|l|}{ AChE } \\
\hline
\end{tabular}

Significant effects $(p<0.05)$ are in boldface; only predictors contributing to the winning models are shown.

Baltic copepods to feeding conditions representative of heavy cyanobacteria bloom conditions in the northern Baltic proper. The primary focus was on evaluating food availability, intake, and growth as confounding variables for the biomarker responses and additional effects of species and diet.

We induced antioxidant and growth responses in the copepods Acartia bifilosa and Eurytemora affinis by manipulating food availability and diet composition, i.e., mixed diet dominated by toxic Nodularia spumigena or the high-quality prey Rhodomonas salina. We observed that SOD, CAT, and GST activities increased with increasing food availability regardless of the diet, with no significant diet effect when nominal food concentration was used as a covariate in the regression analysis (Figure 1; Table 1). However, the pro-oxidative effects of $N$. spumigena became highly significant when antioxidant enzyme activities were compared between the diets while also accounting for the variation in the metabolic responses, i.e., feeding, growth status, and egg production of the animals (Table 3 ). These findings emphasize the importance of complementary assessment of metabolic status in the test species when applying oxidative stress biomarkers in ecological and ecotoxicological studies. They also indicate that grazers feeding on toxic cyanobacteria (and perhaps other phytoplankton species producing bioactive secondary metabolites) have elevated ROS production. Thus, the imbalance between the pro-oxidant processes and the enzymatic antioxidant activities may increase with the increasing contribution of such foods to the diets.

Of the two copepods, E. affinis was less affected by the diet than A. bifilosa; this holds for both enzymatic and metabolic responses (Figures 1 and 2). Moreover, at food concentrations $\leq 125 \mu \mathrm{g} \mathrm{C} \mathrm{L}{ }^{-1}$, which are below average bloom values in the Baltic Sea (Jaanus et al., 2011), E. affinis had a similar feeding rate at different diet treatments as suggested by the gut content response, whereas $A$. bifilosa was feeding less, avoiding the cyanobacteria (Figure $\mathbf{2 H}$ ). These findings are in line with the reported differences in the adaptation strategies to the cyanobacteria blooms between the two species in the Northern Baltic Proper. In E. affinis co-occurring with cyanobacterial blooms, positive effects of Nodularia ingestion on growth, reproductive output, and naupliar survival have been reported (Hogfors et al., 2014; Motwani et al., 2017), indicating that all ontogenetic stages of this species are well-adapted to the cyanotoxins and can efficiently utilize toxin-producing cyanobacteria. Recently, the mechanism for the species-specific growth responses to hepatotoxin-producing cyanobacteria was proposed (Gorokhova et al., 2021). This mechanism is based on environmental and genetic adaptation in the copepod microbiome that harbors higher abundances of toxin-degrading bacteria in E. affinis than in A. bifilosa. The adaptation has evolved in response to the regular co-occurrence of these copepods with blooms of N. spumigena and, perhaps, microcystin-producing Baltic cyanobacteria, such as Dolichospermum (Johansson et al., 2004). The differential responses for biomarkers and physiological variables observed here are in line with the enhanced capacity of E. affinis to handle the cyanobacteria-rich diet and maintain growth. Thus, low-to-medium bloom conditions are likely to stimulate population growth in this copepod, and it is likely that E. affinis relies on these blooms to maintain its production in the Baltic Sea.

Despite the growing applications of oxidative stress diagnostics in ecology, we are only beginning to understand the complexity of extrinsic and intrinsic factors behind oxidative stress in different organisms. We expected to find a positive association between the antioxidant response and feeding, because increased caloric intake facilitates the pro-oxidative processes (Sohal and Weindruch, 1996), i.e., the biochemical reactions directly related to feeding and metabolic rates. The superoxide anion $\left(\mathrm{O}_{2}^{-}\right)$derived from oxidative respiration is the most common ROS and the primary species directly generated in the mitochondrial respiratory chain by converting molecular oxygen to $\mathrm{O}_{2}{ }^{-}$by single-electron transfer (Fleury et al., 2002). Metalloenzymes SOD catalyse the dismutation of $\mathrm{O}_{2}{ }^{-}$to $\mathrm{H}_{2} \mathrm{O}$ and $\mathrm{H}_{2} \mathrm{O}_{2}$, which is then detoxified by CAT and 
glutathione peroxidase (Halliwell, 2006). Thus, the SOD-CAT system is often referred to as the first defense line against oxygen toxicity; moreover, the concerted response of these enzymes is sometimes used to indicate coping with elevated ROS production in ecotoxicological studies. The coordinated response manifested as correlative changes in SOD and CAT activities was reported in invertebrates exposed to chemical contaminants (Gorokhova et al., 2013). In line with that, we found that SOD and CAT activities were positively correlated in both copepod species, suggesting a common mechanism for their induction and regulation. Moreover, both enzymes increased across food availability gradients (Table 1; Figure 1) in concert with increasing food intake, individual RNA levels, and egg production (Table 3). This increase provides yet another evidence that elevated metabolic activity due to variability in feeding is associated with higher production of ROS and consequently induction of antioxidant defenses. In crayfish, ingestion of dietary proteins in excess of metabolic amino acid requirements increases superoxide anion production, resulting in elevated lipid peroxidation in gills (Zenteno et al., 2008). Moreover, not only food quantity but also its quality may affect antioxidant responses as suggested by a decreased activity of CAT and GST in the cladoceran Daphnia commutate experiencing dietary phosphorus limitation (Balseiro et al., 2008) and by a positive correlation between GST and body condition assessed by C:P ratio in copepods (Souza et al., 2010). In line with the latter study, GST activity in E. affinis was driven by food consumption only (Table 3). Therefore, when applying the biomarker approach in laboratory and field investigations to assess animal health status, measuring growth and metabolic status in the test specimens or using appropriate biomarkers for these physiological variables is also crucial.

Although high food availability had a more substantial pro-oxidative effect than the toxic cyanobacterium in our study, oxidative stress was also a possible biochemical mechanism of the cyanobacterial toxicity, especially in Acartia (Table 2). Earlier observed in vivo oxidative stress effects induced by purified microcystins or crude cyanobacterial extracts include depletion of intracellular glutathione, changes in mitochondrial function and apoptosis induction, lipid peroxidation, and modulations of GST, CAT, SOD, and glutathione peroxidase (Pietsch et al., 2001; Ding and Ong, 2003; Zhang et al., 2008). When we accounted for the variability in food consumption, the diet effects on the antioxidant enzyme activities were significant for SOD, CAT, and GST in Acartia, whereas only CAT was significant in Eurytemora (Table 3). Therefore, our observations are in agreement with the known pro-oxidative mode of action of various non-ribosomal peptides produced by cyanobacteria.

The GSTs are a ubiquitous multigene enzyme superfamily involved in detoxifying xenobiotics and natural toxins, such as microcystins (Wiegand and Pflugmacher, 2005), by catalyzing their conjugation with glutathione and making the parent compound more water-soluble. Additionally, GSTs are involved in removing reactive organic hydroperoxides, such as lipid peroxidation products (Pflugmacher et al., 1998; Beattie et al., 2003), thus providing defenses against ROS and their toxic metabolites. However, whereas exposure to the pure microcystins induced GST in Danio rerio, the enzyme activity was suppressed after exposure to the crude extract of Microcystis aeruginosa dominated bloom, probably due to the presence of lipopolysaccharides that may reinforce the effects of microcystins by inhibiting the activity of GSTs (Pietsch et al., 2001; Best et al., 2002). In line with this, a bell-shaped respon: : in GST activity was observed in A. bifilosa. This species was significantly higher in the mixed-diet treatment compared to the Rhodomonas monodiet, with a significant increase at the cyanobacterial concentration of up to $125 \mu \mathrm{g} \mathrm{C} \mathrm{L} \mathrm{L}^{-1}$ followed by $\sim 30 \%$ drop at the highest concentration (Figure 1E). The reduction in GST availability due to the lipopolysaccharide production reported for zebrafish embryos (Best et al., 2002) may deleteriously affect the ability of organisms to detoxify microcystins, presumably through decreased utilization of glutathione for conjugation reactions, although other interpretations of the observed GST dynamic are possible. While the glutathione system is an essential intracellular redox buffer, preventing oxidative injury, it is also a key enzyme in various cellular functions, including protein and DNA synthesis, amino acid transport, metabolism, and cell growth. Moreover, in addition to GST, many other metabolic enzymes are glutathione-dependent, which may, at least partly, explain the sustained dynamics of both enzymatic and organismal responses at higher food concentrations (Figures 1 and 2). Accordingly, low retention of ingested cyanobacteria toxins by copepods is usually observed (Guisande et al., 2002; KozlowskySuzuki et al., 2003) and could be explained by detoxification.

Contrary to the expected unimodal inhibition of $\mathrm{AChE}$ with increasing cyanobacteria concentrations, an unusual response of AChE increasing up to $>50 \%$ at low $\left(\leq 25 \mu \mathrm{g} \mathrm{C} \mathrm{L}^{-1}\right)$ levels of the cyanobacterium was observed in A. bifilosa, whereas no significant response was detected at 125 and $600 \mu \mathrm{g} \mathrm{C} \mathrm{L^{-1 }}$ (Figure 1B). The AChE activity is a popular biomarker to detect a response to organophosphate, carbamate, and metal exposure, with the enzyme inhibition being a sign of chemically-induced neurotoxicity (Sarkar et al., 2006). The commonly observed inhibition of $\mathrm{AChE}$ is linked directly with the mechanism of toxic action, $v i z$. irreversible or reversible binding to the catalytic site of the enzyme and potentiation of cholinergic effects (Sarkar et al., 2006). However, chemically-induced increase in AChE levels has also been observed in various species, including microcrustaceans and other test organisms commonly used in ecotoxicology (Srivatsan, 1999; Jemec et al., 2007; Gorokhova et al., 2013; Eriksson Wiklund et al., 2014), which may be related to various roles of AChE responding to many external stimuli other than in cholinergic neurotransmission (Soreq and Seidman, 2001). Moreover, in $M$. affinis exposed to contaminated sediment under hypoxic conditions, AChE correlated positively with mortality, indicating that elevated AChE activities are associated with physiological stress (Gorokhova et al., 2010, 2013). Therefore, the cyanobacteria-induced AChE stimulation in copepods and possibly other crustacean grazers should be considered when interpreting field measurements of this biomarker in ecotoxicological surveys.

Our study was conducted using copepods collected in the Northern Baltic Proper, where toxic cyanobacterial blooms occurred over 7,000years (Bianchi et al., 2000). Surface aggregations of summer cyanobacteria, including $N$. spumigena (Hajdu et al., 2007), have high cell density and toxin concentrations, thus increasing the potential toxicity to 
zooplankton. Therefore, the copepods in this ecosystem are evolutionarily adapted to cyanotoxins and bioactive compounds produced by this cyanobacterium. However, due to more recent anthropogenic activities, this area is also greatly influenced by direct and indirect toxic contaminants, harmful to biota and humans. Of great interest for ecological assessment for contaminant effects in biota is to provide evidence for how anthropogenic pressures impair essential physiological functions of the Baltic fauna. However, our study shows that toxinproducing algae may act as confounding stressors and cause biological responses (even irreversible damage), including the biomarkers commonly used for biological effect assessment in the context of chemical exposure. Therefore, comprehensive experimental studies with combined exposure to cyanotoxins and chemical mixtures relevant for specific habitats are needed

\section{REFERENCES}

Amado, L. L., and Monserrat, J. M. (2010). Oxidative stress generation by microcystins in aquatic animals: why and how. Environ. Int. 36, 226-235. doi: 10.1016/j.envint.2009.10.010

Balseiro, E., Sol Souza, M., Modenutti, B., and Reissig, M. (2008). Living in transparent lakes: low food $\mathrm{P}: \mathrm{C}$ ratio decreases antioxidant response to ultraviolet radiation in Daphnia. Limnol. Oceanogr. 53, 2383-2390. doi: 10.4319/lo.2008.53.6.2383

Beattie, K. A., Ressler, J., Wiegand, C., Krause, E., Codd, G. A., Steinberg, C. E. W., et al. (2003). Comparative effects and metabolism of two microcystins and nodularin in the brine shrimp Artemia salina. Aquat. Toxicol. 62, 219-226. doi: 10.1016/S0166-445X(02)00091-7

Bednarska, A., Pietrzak, B., and Pijanowska, J. (2014). Effect of poor manageability and low nutritional value of cyanobacteria on Daphnia magna life history performance. J. Plankton Res. 36, 838-847. doi: 10.1093/ plankt/fbu009

Best, J. H., Pflugmacher, S., Wiegand, C., Eddy, F. B., Metcalf, J. S., and Codd, G. A. (2002). Effects of enteric bacterial and cyanobacterial lipopolysaccharides, and of microcystin-LR, on glutathione S-transferase activities in zebra fish (Danio rerio). Aquat. Toxicol. 60, 223-231. doi: 10.1016/S0166-445X(02)00010-3

Bianchi, T. S., Engelhaupt, E., Westman, P., Andrén, T., Rolff, C., and Elmgren, R. (2000). Cyanobacterial blooms in the Baltic Sea: natural or human-induced? Limnol. Oceanogr. 45, 716-726. doi: 10.4319/lo.2000.45.3.0716

Bocquené, G., and Galgani, F. (1998). Biological effects of contaminants: cholinesterase inhibition by organophosphate and carbamate compounds. ICES Tech. Mar. Environ. Sci. 20, 1-22.

Cohen, A. A., McGraw, K. J., and Robinson, W. D. (2009). Serum antioxidant levels in wild birds vary in relation to diet, season, life history strategy, and species. Oecologia 161, 673-683. doi: 10.1007/s00442-009-1423-9

Davies, W. R., Siu, W. H. L., Jack, R. W., Wu, R. S. S., Lam, P. K. S., and Nugegoda, D. (2005). Comparative effects of the blue green algae Nodularia spumigena and a lysed extract on detoxification and antioxidant enzymes in the green lipped mussel (Perna viridis). Mar. Pollut. Bull. 51, 1026-1033. doi: 10.1016/j.marpolbul.2005.01.008

Ding, W.-X., and Ong, C. (2003). Role of oxidative stress and mitochondrial changes in cyanobacteria-induced apoptosis and hepatotoxicity. FEMS Microbiol. Lett. 220, 1-7. doi: 10.1016/S0378-1097(03)00100-9

Ellman, G., Courtney, K., Andres, V., and Featherstone, R. (1961). A new and rapid colorimetric determination of acetylcholinesterase activity. Biochem. Pharmacol. 7, 88-95. doi: 10.1016/0006-2952(61)90145-9

Engström-Öst, J., Brutemark, A., Vehmaa, A., Motwani, N. H., and Katajisto, T. (2015). Consequences of a cyanobacteria bloom for copepod reproduction, mortality and sex ratio. J. Plankton Res. 37, 388-398. doi: 10.1093/plankt/ fbv004

Engström-Öst, J., Hogfors, H., El-Shehawy, R., Stasio, B. D., Vehmaa, A., and Gorokhova, E. (2011). Toxin-producing cyanobacterium Nodularia spumigena, to select informative test species, biomarkers, and covariates, such as food intake and growth-related variables, to use biomarker approaches in the environmental assessment of chemical stressors.

\section{DATA AVAILABILITY STATEMENT}

The raw data supporting the conclusions of this article will be made available by the authors, without undue reservation.

\section{AUTHOR CONTRIBUTIONS}

EG designed the experiments. EG and RE analyzed the results and wrote the manuscript. All authors contributed to the article and approved the submitted version.

potential competitors and grazers: testing mechanisms of reciprocal interactions. Aquat. Microb. Ecol. 62, 39-48. doi: 10.3354/ame01456

Eriksson Wiklund, A.-K. E., Adolfsson-Erici, M., Liewenborg, B., and Gorokhova, E. (2014). Sucralose induces biochemical responses in Daphnia magna. PLoS One 9:e92771. doi: 10.1371/journal.pone.0092771

Fleury, C., Mignotte, B., and Vayssiere, J. (2002). Mitochondrial reactive oxygen species in cell death signaling. Biochimie 84, 131-141. doi: 10.1016/ S0300-9084(02)01369-X

Flohé, L., and Ötting, F. (1985). Superoxide dismutase assays. Methods Enzymol. 105, 93-105. doi: 10.1016/s0076-6879(84)05013-8

Frasco, M. F., and Guilhermino, L. (2002). Effects of dimethoate and betanaphthoflavone on selected biomarkers of Poecilia reticulata. Fish Physiol. Biochem. 26, 149-156. doi: 10.1023/A:1025457831923

Furuhagen, S., Liewenborg, B., Breitholtz, M., and Gorokhova, E. (2014). Feeding activity and xenobiotics modulate oxidative status in Daphnia magna: implications for ecotoxicological testing. Environ. Sci. Technol. 48, 12886-12892. doi: $10.1021 /$ es5044722

Gorokhova, E. (2005). Effects of preservation and storage of microcrustaceans in RNAlater on RNA and DNA degradation. Limnol. Oceanogr. Methods 3, 143-148. doi: 10.4319/lom.2005.3.143

Gorokhova, E. (2009). Toxic cyanobacteria Nodularia spumigena in the diet of Baltic mysids: evidence from molecular diet analysis. Harmful Algae 8, 264-272. doi: 10.1016/j.hal.2008.06.006

Gorokhova, E. (2010). A single-step staining method to evaluate egg viability in zooplankton. Limnol. Oceanogr. Methods 8, 414-423. doi: 10.4319/ lom.2010.8.414

Gorokhova, E., El-Shehawy, R., Lehtiniemi, M., and Garbaras, A. (2021). How copepods can eat toxins without getting sick: gut bacteria help zooplankton to feed in cyanobacteria blooms. Front. Microbiol. 11:589816. doi: 10.3389/ fmicb.2020.589816

Gorokhova, E., and Engström-Öst, J. (2009). Toxin concentration in Nodularia spumigena is modulated by mesozooplankton grazers. J. Plankton Res. 31, 1235-1247. doi: 10.1093/plankt/fbp060

Gorokhova, E., and Kyle, M. (2002). Analysis of nucleic acids in Daphnia: development of methods and ontogenetic variations in RNA-DNA content. J. Plankton Res. 24, 511-522. doi: 10.1093/plankt/24.5.511

Gorokhova, E., Löf, M., Halldórsson, H. P., Tjärnlund, U., Lindström, M., Elfwing, T., et al. (2010). Single and combined effects of hypoxia and contaminated sediments on the amphipod Monoporeia affinis in laboratory toxicity bioassays based on multiple biomarkers. Aquat. Toxicol. 99, 263-274. doi: 10.1016/j.aquatox.2010.05.005

Gorokhova, E., Löf, M., Reutgard, M., Lindström, M., and Sundelin, B. (2013). Exposure to contaminants exacerbates oxidative stress in amphipod Monoporeia affinis subjected to fluctuating hypoxia. Aquat. Toxicol. 127, 46-53. doi: 10.1016/j.aquatox.2012.01.022

Guisande, C., Frangópulos, M., Carotenuto, Y., Maneiro, I., Riveiro, I., and Vergara, A. R. (2002). Fate of paralytic shellfish poisoning toxins ingested 
by the copepod Acartia clausi. Mar. Ecol. Prog. Ser. 240, 105-115. doi: 10.3354/meps240105

Gulati, R., and DeMott, W. (1997). The role of food quality for zooplankton: remarks on the state-of-the-art, perspectives and priorities. Freshw. Biol. 38, 753-768. doi: $10.1046 /$ j.1365-2427.1997.00275.x

Habig, W. H., and Jakoby, W. B. (1981). Assays for differentiation of glutathione S-transferases. Methods Enzymol. 77, 398-405. doi: 10.1016/ S0076-6879(81)77053-8

Hajdu, S., Höglander, H., and Larsson, U. (2007). Phytoplankton vertical distributions and composition in Baltic Sea cyanobacterial blooms. Harmful Algae 6, 189-205. doi: 10.1016/j.hal.2006.07.006

Halliwell, B. (2006). Reactive species and antioxidants. Redox biology is a fundamental theme of aerobic life. Plant Physiol. 141, 312-322. doi: 10.1104/ pp.106.077073

Hogfors, H., Motwani, N. H., and Hajdu, S., and others. 2014. Bloom-forming cyanobacteria support copepod reproduction and development in the Baltic Sea. PLoS One 9: e112692. doi:10.1371/journal.pone.0112692

Holmborn, T., Dahlgren, K., Holeton, C., Hogfors, H., and Gorokhova, E. (2009). Biochemical proxies for growth and metabolism in Acartia bifilosa (Copepoda, Calanoida): biomarkers of copepod feeding status. Limnol. Oceanogr. Methods 7, 785-794. doi: 10.4319/lom.2009.7.785

Höök, T. O., Gorokhova, E., and Hansson, S. (2008). RNA:DNA ratios of Baltic Sea herring larvae and copepods in embayment and open sea habitats. Estuar. Coast. Shelf Sci. 76, 29-35. doi: 10.1016/j.ecss.2007.06.012

Jaanus, A., Andersson, A., Olenina, I., Toming, K., and Kaljurand, K. (2011). Changes in phytoplankton communities along a north-south gradient in the Baltic Sea between 1990 and 2008. Boreal Environ. Res. 16, 191-208.

Janssens, B. J., Childress, J. J., Baguet, F., and Rees, J. F. (2000). Reduced enzymatic antioxidative defense in deep-sea fish. J. Exp. Biol. 203, 3717-3725. doi: $10.1242 /$ jeb.203.24.3717

Jemec, A., Drobne, D., Tišler, T., Trebše, P., Roš, M., and Sepčić, K. (2007). The applicability of acetylcholinesterase and glutathione S-transferase in Daphnia magna toxicity test. Comp. Biochem. Physiol. C Toxicol. Pharmacol. 144, 303-309. doi: 10.1016/j.cbpc.2006.10.002

Johansson, M., Gorokhova, E., and Larsson, U. (2004). Annual variability in ciliate community structure, potential prey and predators in the open northern Baltic Sea proper. J. Plankton Res. 26, 67-80. doi: 10.1093/plankt/fbg115

Jones, L. J., Haugland, R. P., and Singer, V. L. (2003). Development and characterization of the NanoOrange protein quantitation assay: a fluorescencebased assay of proteins in solution. Biotechniques 34, 850-854, 856, 858 passim. doi: $10.2144 / 03344 \mathrm{pt} 03$

Jos, A., Pichardo, S., Prieto, A. I., Repetto, G., Vázquez, C. M., Moreno, I., et al. (2005). Toxic cyanobacterial cells containing microcystins induce oxidative stress in exposed tilapia fish (Oreochromis sp.) under laboratory conditions. Aquat. Toxicol. 72, 261-271. doi: 10.1016/j. aquatox.2005.01.003

Kankaanpää, H., Leiniö, S., Olin, M., Sjövall, O., Meriluoto, J., and Lehtonen, K. K. (2007). Accumulation and depuration of cyanobacterial toxin nodularin and biomarker responses in the mussel Mytilus edulis. Chemosphere 68, 1210-1217. doi: 10.1016/j.chemosphere.2007.01.076

Karjalainen, M., Reinikainen, M., Lindvall, F., Spoof, L., and J. a. O. Meriluoto., (2003). Uptake and accumulation of dissolved, radiolabeled nodularin in Baltic Sea zooplankton. Environ. Toxicol. 18, 52-60. doi: 10.1002/tox.10100

Kopecka, J., Lehtonen, K. K., Barsiene, J., Broeg, K., Vuorinen, P. J., Gercken, J., et al. (2006). Measurements of biomarker levels in flounder (Platichthys flesus) and blue mussel (Mytilus trossulus) from the Gulf of Gdańsk (southern Baltic). Mar. Pollut. Bull. 53, 406-421. doi: 10.1016/j.marpolbul.2006.03.008

Koski, M., Engström, J., and Viitasalo, M. (1999). Reproduction and survival of the calanoid copepod Eurytemora affinis fed with toxic and non-toxic cyanobacteria. Mar. Ecol. Prog. Ser. 186, 187-197. doi: 10.3354/meps186187

Kozlowsky-Suzuki, B., Karjalainen, M., Lehtiniemi, M., Engström-Öst, J., Koski, M., and Carlsson, P. (2003). Feeding, reproduction and toxin accumulation by the copepods Acartia bifilosa and Eurytemora affinis in the presence of the toxic cyanobacterium Nodularia spumigena. Mar. Ecol. Prog. Ser. 249, 237-249. doi: $10.3354 /$ meps 249237

Kozlowsky-Suzuki, B., Koski, M., Hallberg, E., Wallén, R., and Carlsson, P. (2009). Glutathione transferase activity and oocyte development in copepods exposed to toxic phytoplankton. Harmful Algae 8, 395-406. doi: 10.1016/j. hal.2008.08.025
Lage, S., Mazur-Marzec, H., and Gorokhova, E. (2021). Competitive interactions as a mechanism for chemical diversity maintenance in Nodularia spumigena. Sci. Rep. 11, 8970. doi: 10.1038/s41598-021-88361-x

Lampert, W. (1987). Laboratory studies on zooplankton-cyanobacteria interactions. N. Z. J. Mar. Freshw. Res. 21, 483-490. doi: 10.1080/00288330. 1987.9516244

Lehtonen, K. K., Leiniö, S., Schneider, R., and Leivuori, M. (2006). Biomarkers of pollution effects in the bivalves Mytilus edulis and Macoma balthica collected from the southern coast of Finland (Baltic Sea). Mar. Ecol. Prog. Ser. 322, 155-168. doi: 10.3354/meps322155

Lionetto, M. G., Caricato, R., Calisi, A., Giordano, M. E., and Schettino, T. (2013). Acetylcholinesterase as a biomarker in environmental and occupational medicine: new insights and future perspectives. Biomed. Res. Int. 2013, 1-8. doi: $10.1155 / 2013 / 321213$

Maral, J., Puget, K., and Michelson, A. M. (1977). Comparative study of superoxide dismutase, catalase and glutathione peroxidase levels in erythrocytes of different animals. Biochem. Biophys. Res. Commun. 77, 1525-1535. doi: 10.1016/S0006-291X(77)80151-4

Marie, B., Genard, B., Rees, J.-F., and Zal, F. (2006). Effect of ambient oxygen concentration on activities of enzymatic antioxidant defences and aerobic metabolism in the hydrothermal vent worm, Paralvinella grasslei. Mar. Biol. 150, 273-284. doi: 10.1007/s00227-006-0338-9

Moffitt, M. C., Blackburn, S. I., and Neilan, B. A. (2001). rRNA sequences reflect the ecophysiology and define the toxic cyanobacteria of the genus Nodularia. Int. J. Syst. Evol. Microbiol. 51, 505-512. doi: 10.1099/00207713-51-2-505

Monserrat, J. M., Martínez, P. E., and Geracitano, L. A., and others. 2007. Pollution biomarkers in estuarine animals: critical review and new perspectives. Comp. Biochem. Physiol. C Toxicol. Pharmacol. 146: 221-234. doi:10.1016/j. cbpc.2006.08.012

Motwani, N. H., Duberg, J., Svedén, J. B., and Gorokhova, E. (2017). Grazing on cyanobacteria and transfer of diazotrophic nitrogen to zooplankton in the Baltic Sea. Limnol. Oceanogr. 63, 672-686. doi: 10.1002/ $\operatorname{lno} 10659$

Mullin, M. M., Sloan, P. R., and Eppley, R. W. (1966). Relationship between carbon content, cell volume, and area in phytoplankton. Limnol. Oceanogr 11, 307-311. doi: 10.4319/lo.1966.11.2.0307

Napierska, D., Barsiene, J., Mulkiewicz, E., Podolska, M., and Rybakovas, A. (2009). Biomarker responses in flounder Platichthys flesus from the polish coastal area of the Baltic Sea and applications in biomonitoring. Ecotoxicology 18, 846-859. doi: 10.1007/s10646-009-0328-Z

Neilan, B. A., Jacobs, D., Del Dot, T., Blackall, L. L., Hawkins, P. R., Cox, P. T., et al. (1997). rRNA sequences and evolutionary relationships among toxic and nontoxic cyanobacteria of the genus Microcystis. Int. J. Syst. Bacteriol. 47, 693-697. doi: 10.1099/00207713-47-3-693

Olenina, I., Hajdu, S., Edler, L., Andersson, A., Wasmund, N., Busch, S., et al. (2006). Biovolumes and size-classes of phytoplankton in the Baltic Sea. HELCOM Balt. Sea Environ. Proc. 166:144.

Persson, K.-J., Legrand, C., and Olsson, T. (2009). Detection of nodularin in European flounder (Platichthys flesus) in the west coast of Sweden: evidence of nodularin mediated oxidative stress. Harmful Algae 8, 832-838. doi: 10.1016/j.hal.2009.03.003

Peters, J., Renz, J., van Beusekom, J., Boersma, M., and Hagen, W. (2006). Trophodynamics and seasonal cycle of the copepod Pseudocalanus acuspes in the Central Baltic Sea (Bornholm Basin): evidence from lipid composition. Mar. Biol. 149, 1417-1429. doi: 10.1007/s00227-006-0290-8

Pflugmacher, S., Wiegand, C., Oberemm, A., Beattie, K. A., Krause, E., Codd, G. A., et al. (1998). Identification of an enzymatically formed glutathione conjugate of the cyanobacterial hepatotoxin microcystin-LR: the first step of detoxication. Biochim. Biophys. Acta 1425, 527-533. doi: 10.1016/S0304-4165(98)00107-X

Pietsch, C., Wiegand, C., Amé, M. V., Nicklisch, A., Wunderlin, D., and Pflugmacher, S. (2001). The effects of a cyanobacterial crude extract on different aquatic organisms: evidence for cyanobacterial toxin modulating factors. Environ. Toxicol. 16, 535-542. doi: 10.1002/tox.10014

Pinho, G. L. L., Moura da Rosa, C., Yunes, J. S., Luquet, C. M., Bianchini, A., and Monserrat, J. M. (2003). Toxic effects of microcystins in the hepatopancreas of the estuarine crab Chasmagnathus granulatus (Decapoda, Grapsidae). Comp. Biochem. Physiol. C Toxicol. Pharmacol. 135, 459-468. doi: 10.1016/ S1532-0456(03)00147-9 
Pisoschi, A. M., and Pop, A. (2015). The role of antioxidants in the chemistry of oxidative stress: A review. Eur. J. Med. Chem. 97, 55-74. doi: 10.1016/j. ejmech.2015.04.040

Sarkar, A., Ray, D., Shrivastava, A. N., and Sarker, S. (2006). Molecular biomarkers: their significance and application in marine pollution monitoring. Ecotoxicology 15, 333-340. doi: 10.1007/s10646-006-0069-1

Sellner, K. G., Olson, M. M., and Olli, K. (1996). Copepod interactions with toxic and non-toxic cyanobacteria from the Gulf of Finland. Phycologia 35, 177-182. doi: 10.2216/i0031-8884-35-6S-177.1

Sies, H., Berndt, C., and Jones, D. P. (2017). Oxidative stress. Annu. Rev. Biochem. 86, 715-748. doi: 10.1146/annurev-biochem-061516-045037

Sivonen, K., and Börner, T. (2008). "Bioactive compounds produced by cyanobacteria," in The Cyanobacteria: Molecular Biology, Genomics and Evolution. eds. A. Herraro and E. Flores (Hethersett, UK: Caister Academic Press), 159-197.

Sivonen, K., Kononen, K., Esala, A.-L., and Niemelä, S. I. (1989). Toxicity and isolation of the cyanobacterium Nodularia spumigena from the southern Baltic Sea in 1986. Hydrobiologia 185, 3-8. doi: 10.1007/BF00006062

Sohal, R. S., and Weindruch, R. (1996). Oxidative stress, caloric restriction, and aging. Science 273, 59-63. doi: 10.1126/science.273.5271.59

Soreq, H., and Seidman, S. (2001). Acetylcholinesterase - new roles for an old actor. Nat. Rev. Neurosci. 2, 294-302. doi: 10.1038/35067589

Souza, M. S., Modenutti, B. E., Carrillo, P., Villar-Argaiz, M., Medina-Sánchez, J. M., Bullejos, F., et al. (2010). Stoichiometric dietary constraints influence the response of copepods to ultraviolet radiation-induced oxidative stress. Limnol. Oceanogr. 55, 1024-1032. doi: 10.4319/lo.2010.55.3.1024

Srivatsan, M. (1999). Effects of organophosphates on cholinesterase activity and neurite regeneration in Aplysia. Chem. Biol. Interact. 119-120, 371-378. doi: 10.1016/S0009-2797(99)00048-4

Troedsson, C., Simonelli, P., Nägele, V., Nejstgaard, J. C., and Frischer, M. E. (2009). Quantification of copepod gut content by differential length amplification quantitative PCR (dla-qPCR). Mar. Biol. 156, 253-259. doi: 10.1007/s00227-008-1079-8

Vehmaa, A., Hogfors, H., Gorokhova, E., Brutemark, A., Holmborn, T., and Engström-Öst, J. (2013). Projected marine climate change: effects on copepod oxidative status and reproduction. Ecol. Evol. 3, 4548-4557. doi: 10.1002/ ece 3.839

Wiegand, C., and Pflugmacher, S. (2005). Ecotoxicological effects of selected cyanobacterial secondary metabolites: a short review. Toxicol. Appl. Pharmacol. 203, 201-218. doi: 10.1016/j.taap.2004.11.002

Zenteno-Savin, T., Cortes-Jacinto, E., Vázquez-Medina, J. P., and Villarreal-Colmenares, H. (2008). Oxidative damage in tissues of juvenile crayfish (Cherax quadricarinatus von Martens, 1868) fed different levels of proteins and lipid. Hidrobiológica 18, 147-154.

Zhang, H., Zhang, J., Chen, Y., and Zhu, Y. (2008). Microcystin-RR induces apoptosis in fish lymphocytes by generating reactive oxygen species and causing mitochondrial damage. Fish Physiol. Biochem. 34, 307-312. doi: 10.1007/s10695-007-9189-7

Zuur, A. F., Ieno, E. N., and Elphick, C. S. (2010). A protocol for data exploration to avoid common statistical problems. Methods Ecol. Evol. 1, 3-14. doi: 10.1111/j.2041-210X.2009.00001.x

Conflict of Interest: The authors declare that the research was conducted in the absence of any commercial or financial relationships that could be construed as a potential conflict of interest.

Publisher's Note: All claims expressed in this article are solely those of the authors and do not necessarily represent those of their affiliated organizations, or those of the publisher, the editors and the reviewers. Any product that may be evaluated in this article, or claim that may be made by its manufacturer, is not guaranteed or endorsed by the publisher.

Copyright (C) 2022 Gorokhova and El-Shehawy. This is an open-access article distributed under the terms of the Creative Commons Attribution License (CC BY). The use, distribution or reproduction in other forums is permitted, provided the original author(s) and the copyright owner(s) are credited and that the original publication in this journal is cited, in accordance with accepted academic practice. No use, distribution or reproduction is permitted which does not comply with these terms. 